\title{
Tradition and Change in Nineteenth-Century Iowa Farmhouses
}

\author{
FRED W. PETERSON
}

THE EUROPEAN-AMERICAN SETTLERS who arrived in Iowa beginning in the 1840 s brought many traditions with them. Those traditions included material forms as well as beliefs, values, and practices. One of the traditional forms they imposed on the Iowa landscape was a distinctive type of house known as the I-house. ${ }^{1}$

The typical I-house built in Iowa was a two-story structure with end gables, two rooms long and one room deep. With its central door and flanking windows on the long principal facade, it displayed an appealing symmetry (fig. 1). The first floor of a typical I-house consisted of a dining room and parlor usually of equal size with a staircase either centrally dividing the two chambers or located on the back wall of one of the rooms. That staircase gave access to two bedrooms on the second story. A wing on the back of the house provided space for a kitchen conveniently accessible to the dining room and the parlor. ${ }^{2}$ Iowa farmers usually built the I-house,

1. This study of I-houses is based on surveys of rural Iowa that I made in 1980-81, 1984-85, 1985-86, and 1991-92. I located more than five hundred I-houses and photographed more than fifty. Images of I-houses recorded in A. T. Andreas' Illustrated Historical Atlas of the State of Iowa (Chicago, 1875), county histories, and the photographic collection of the State Historical Society of Iowa in Iowa City supplied information about structures that have not survived. Another study that includes Iowa in a survey of farmhouse types is Brian P. Birch, Farmhousing in the United States' Corn Belt in 1970 (Southampton, England, 1974), which identifies the house-type as "the Midwest I."

2. Fred Kniffen illustrates and defines the I-house type in "Folk Housing: THE ANNALS OF IOWA 52 (Summer 1993). (C)The State Historical Society of Iowa, 1993. 
including the kitchen wing, in one stage of construction. The symmetry of the facade and the appealing design, with its simple, proportioned spaces, provided convenience in use that satisfied both aesthetic preferences and practical needs of nineteenth-century Anglo-American farm families. ${ }^{3}$

The I-house type originated in folk building practices in sixteenth-century Elizabethan England. Colonists translated the type to America in the seventeenth century. Originally established in the mid-Atlantic states, the house type spread throughout the upper South and westward to the new territories. ${ }^{4}$ The pioneers who brought the I-house type to Iowa

Key to Diffusion," Annals of the Association of American Geographers 55 (1965), 553-55, as having "gables to the side, at least two rooms in length, one room deep, and two full stories in height." He also acknowledges that construction materials of the type varied and that "The floor plan was found to be highly variable. Lateral and rear appendages, front and rear porches, galleries, even classical columns appeared in great variety." Kniffen, and later Henry Glassie, focus on the " $\mathrm{I}$ " section of the house-type as the determinant of its qualities, and although some of their examples of the house type clearly show a kitchen wing at the rear of the house, they subordinate this section of the structure as a variable. See Henry Glassie, Folk Housing in Middle Virginia: A Structural Analysis of Historic Artifacts (Knoxville, TN, 1975). Many I-houses in England and a great number in the United States have a kitchen wing at the rear of the house. Every I-house that I have observed and studied in Iowa has had a kitchen wing at the rear of the house. By the time the house-type reached the upper Midwest, this "variable" had become a constant.

The names given the various chambers of a typical I-house are not necessarily the same as those the original occupants of the houses would have used. It is virtually impossible to know the architectural vocabulary of Anglo-American settlers in Iowa. One can, however, infer that the emerging influences from architectural stylebooks and Victorian prescriptive literature about home life would have broadened choice and use of terms beyond hall, parlor, chamber, and kitchen to include parlor, dining room, living room, bedroom, closet, and pantry.

3. The I-house with kitchen wing should not be confused with the upright and wing house type. The latter was frequently built in two stages with the wing as a lateral extension of the house along a roadside orientation and not to the rear of the house. The balloon-frame ell/T-plan house type was also usually built in stages and was popular from the $1860 \mathrm{~s}$ to the 1880 s as an asymmetrical design that satisfied a taste for picturesque beauty. See Fred W. Peterson, Homes in the Heartland: Balloon Frame Farmhouses of the Upper Midwest, 1850-1920 (Lawrence, KS, 1992), 96-111.

4. See Kniffen, "Folk Housing," 549-77. Another source for the I-house has been traced to northern European log building. See Terry G. Jordan, American Log Buildings: An Old World Heritage (Chapel Hill, NC, 1985). 


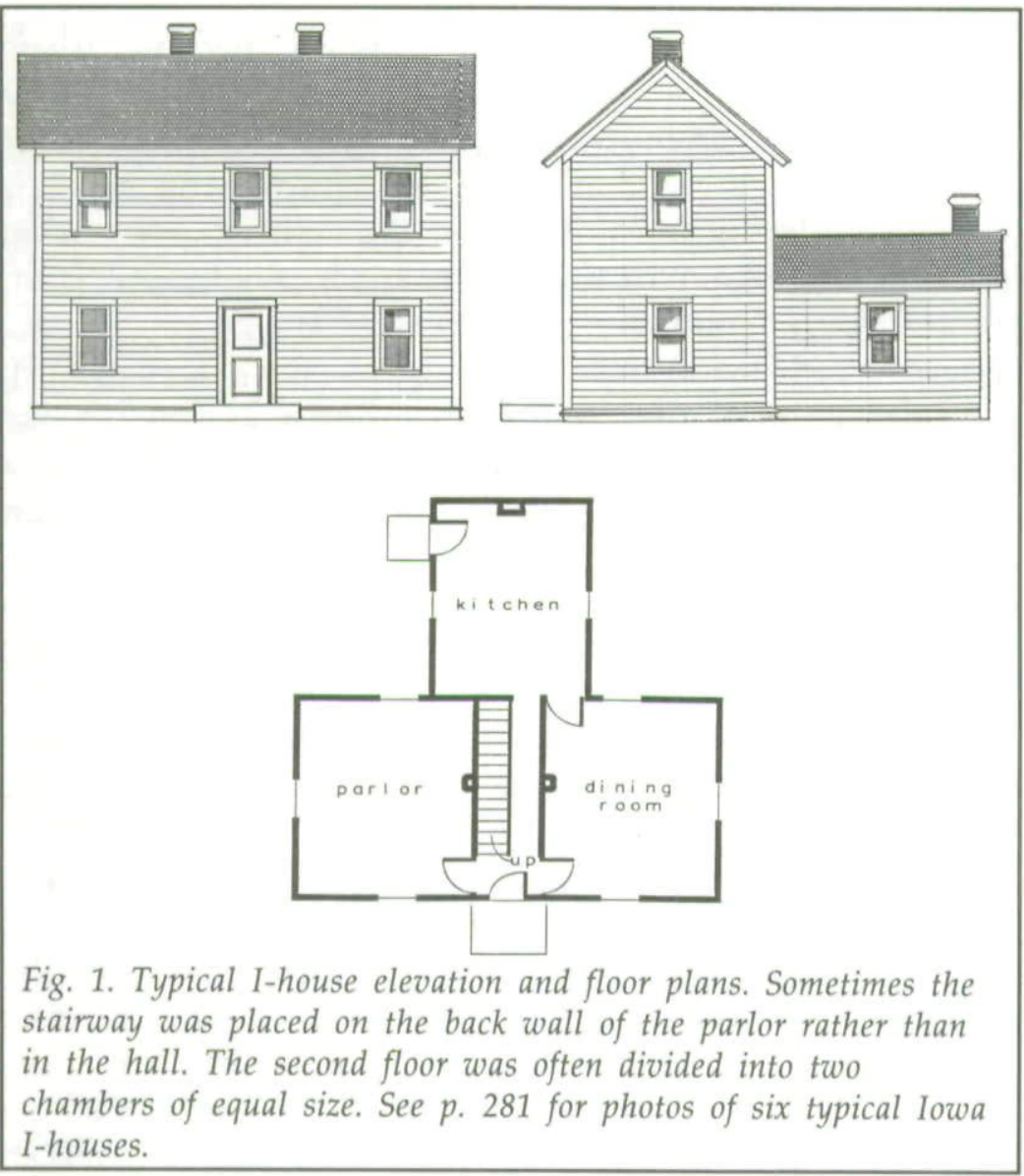

migrated from Indiana, Illinois, Missouri, Kentucky, and Ohio as well as New England, New York, and Pennsylvania. The majority of these settlers were of Anglo-American heritagecitizens who were among the first to arrive in new areas on the frontier and transplant their traditional ways of doing things to the new environment. ${ }^{5}$

As these Anglo-American settlers in Iowa built I-houses on their farms, they were perpetuating a traditional form

5. In the 1860 s and 1870 s Iowans of Anglo-American background outnumbered all other ethnic groups in the state by a ratio of about five to one. See John A. T. Hull, comp., Iowa Historical and Comparative Census, 1836-1880 (Des Moines, 1883), 21. See also Allan G. Bogue, "Farming in the Prairie Peninsula, 1830-1890," Journal of Economic History 23 (1963), 4. 
inherited from previous generations. But during this transfer of tradition and over succeeding generations, individuals inevitably modified the form. For example, they adopted new building technologies that altered the structure by substituting balloon-frame construction for the earlier box frames or brick or stone construction. They made changes to incorporate new amenities such as heating stoves and cooking ranges, which made their homes more effective shelters. In the later years of the nineteenth century, as rural Iowans were able to choose from a wider range of architectural styles, they made choices that reflected their long-term commitment to their dwellings and their status in the community. They also adapted changing tastes in architectural styles to identify with prescriptive values and beliefs about family and home that influenced house design and function during the second half of the nineteenth century. These changes, however, did not alter the essential characteristics of the traditional form.

In transmitting and transforming the I-house type, Iowa farm families adapted their domestic environment to the new, modern economic and social conditions of an industrializing society and the technological values it spawned. They were neither intentionally challenging nor consciously submitting to the authority of traditional ways. Instead, they modified inherited ways of doing things to satisfy pressing needs, to provide for more efficient ways of accomplishing household tasks, or to take advantage of new products and technologies. ${ }^{6}$ The individuals involved in these changes did not necessarily see them as radically altering traditional practices. Each generation of "young folks" absorbed "the old ways" of their parents, then modified and transmitted them to the next generation. $^{7}$

6. See John A. Kouwenhoven, "Democracy, Machines, and Vernacular Design," in Half a Truth Is Better Than None: Some Unsystematic Conjectures about Art, Disorder, and American Experience (Chicago, 1982), 75-105.

7. See Edward Shils, Tradition (Chicago, 1981); and Yi-Fu Tuan, "Traditional: What Does It Mean," in Jean-Paul Bourdier and Nezar Alsayyad, eds., Dwellings, Settlements, and Tradition: Cross Cultural Perspectives (Lanham, MD, 1989), 27-34. 
The house as a type is a cluster of related ideas, images, and values that determine the practical, moral, and spiritual aspects of planning and building a house. Included in this cluster are conceptions of a house as structure, shelter, dwelling, and home. These four related concepts help define the nature and explain the transmission of the I-house type in time and space.

AN IMAGE of the I-house type as structure in the mind of the builder was basic to the perpetuation of the traditional form of the house. ${ }^{8}$ Structure is the fundamental spatial organization of the house, including its size and scale, the number and arrangement of rooms, and the materials and methods of construction. Memory, practical knowledge, and manual skills enabled builders to realize structure in physical form. They reproduced the type by building houses that incorporated generic qualities of structure. Of course, the specific economies, materials, and methods varied in each construction process. The challenge to the builders' ingenuity and inventiveness came as they tried to play variations on the basic floor plan and elevation of the house type while retaining its essential structural characteristics.

Because the floor plan and elevation remained relatively constant, the major structural variations related to construction materials and methods, particularly framing techniques. Some of the early Iowa I-houses, such as the Edwin G. Hosch farmhouse near Cascade or the Samuel Nichols dwelling near Nichols were built of stone or brick (figs. 2 and 3). Among the wood frame houses, three framing techniques were used to construct the house type. Box-frame construction employed heavy timbers fastened together with mortise-andtenon joints. An industrialized process called balloon-frame construction used pieces of milled lumber held together by mass-produced nails to create a lightweight, easy-to-build frame. Braced-frame construction was a cautious compromise

8. Important treatments of the qualities of house-type here labeled structure are found in Glassie, Folk Housing; and Dell Upton, "The Power of Things: Recent Studies in American Vernacular Architecture," American Quarterly 35 (1983), 270-77. 


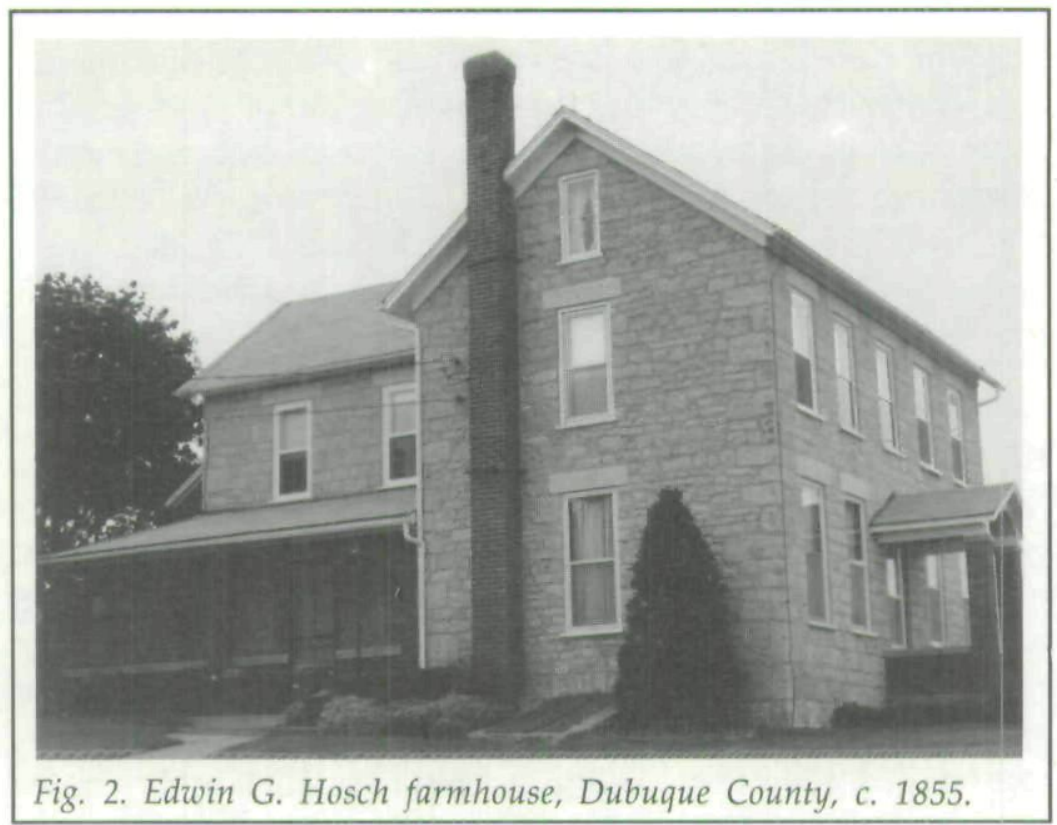

between box-frame and balloon-frame construction; both nails and mortise-and-tenon joints joined relatively heavy, large-dimension lumber to form a sturdy frame. Even after balloon-frame construction came into use in the Midwest during the 1830s, some builders continued to use earlier boxframe or braced-frame construction. Furthermore, even as Yankee farmers and carpenters in Iowa gradually began to take advantage of the economies and efficiencies of the new balloon-frame technique, they continued to think and work in terms of a traditional I-house type structure. ${ }^{9}$

9. A balloon-frame structure results from the joining of sill, joist, studs, lath, rafters, sheathing, shiplap siding, braces, and supports with iron or steel nails into a tight network of members characterized as a basket insofar as every member of the frame adds strength to other members in a complete integrity of the structure. The members of the frame are massproduced pieces of standardized dimension lumber, such as $2^{\prime \prime} \times 4^{\prime \prime}, 2^{\prime \prime} \times$ $6^{\prime \prime}, 2^{\prime \prime} \times 8^{\prime \prime}, 2^{\prime \prime} \times 10^{\prime \prime}, 1^{\prime \prime} \times 6^{\prime \prime}$, and $1^{\prime \prime} \times 8^{\prime \prime}$ boards. For a discussion of the origins of balloon-frame construction, see Walker Field, "A Reexamination into the Invention of the Balloon Frame," Journal of Architectural Historians (October 1942), 3-29; and Paul E. Sprague, "Chicago Balloon Frame: The Evolution During the Nineteenth Century of George W. Snow's System of Erecting Light Frame Buildings from Dimension Lumber 


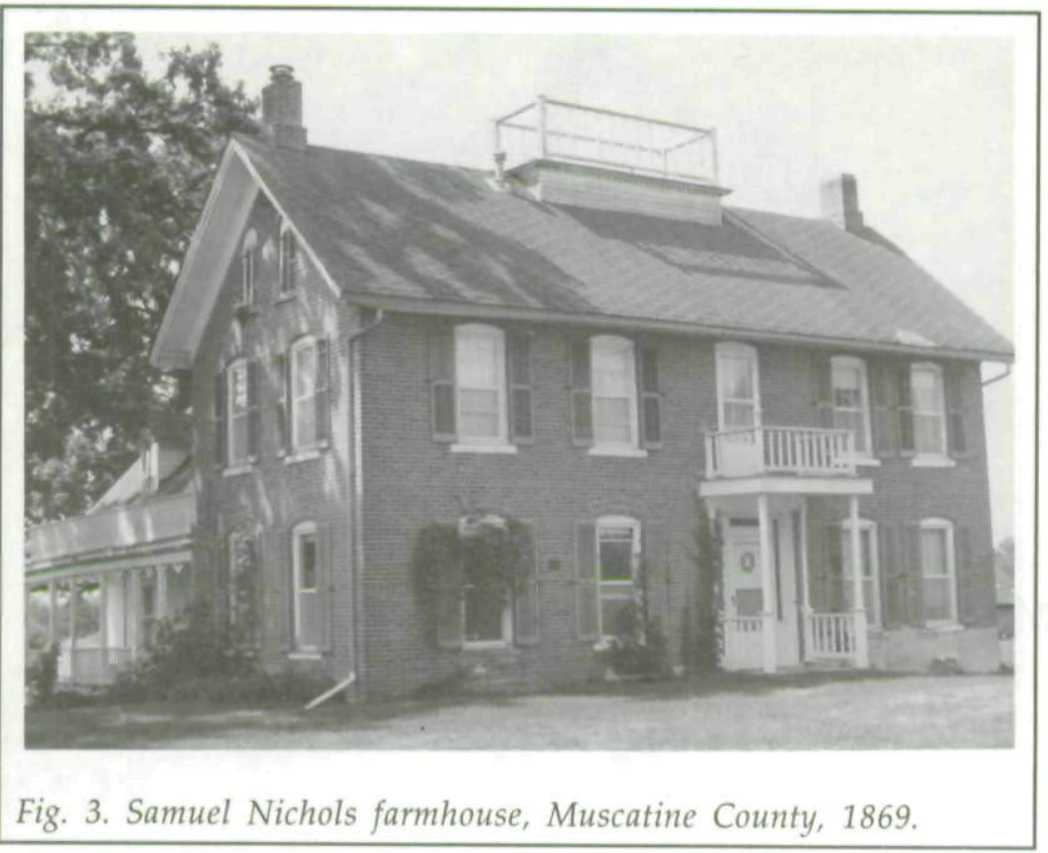

A farmhouse near Atalissa illustrates how its builder used a box frame with mortise-and-tenon joints to create traditional interior spaces but also to introduce variations in the construction and appearance of the I-house (fig. 4). The structure was built in two phases. Originally constructed in the 1840 s, it was completed about forty years later. ${ }^{10}$ In its first phase, the house was one-and-a-half stories in elevation. It displayed the distinguishing traits of end gable walls enclosing two rooms, with a staircase dividing the space of the first floor and giving access to the half-story. The location of the chimneys on the end gable walls was also typical. The lightweight members of the frame,

and Machine-made Nails," Technology of Historic American Buildings (Washington, DC, 1983), 35-61.

10. I initially studied this house in late summer 1985 , when it was abandoned and standing in a field of tall Iowa corn. I returned to the site in early spring 1988 to take photographs of the structure in the open space of the field before any crops were in. The house had been burned to the ground approximately a week before my visit. I was, however, able to analyze the ruins thoroughly to determine the ways the house was structured. 

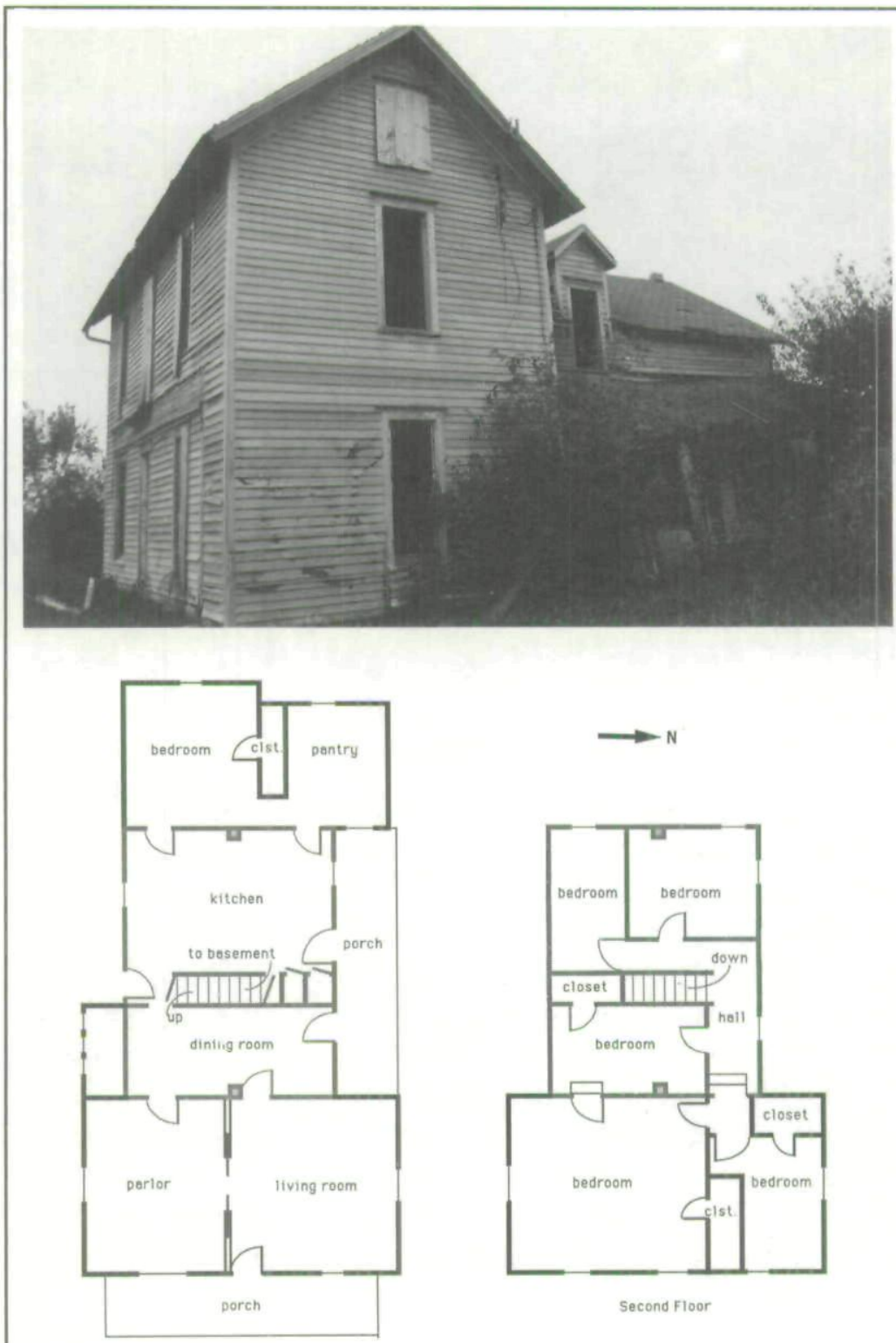

Second Floor

First Floor

Fig. 4. Two-phase box-frame/balloon-frame farmhouse, Muscatine County, c. 1840-1880. The kitchen and dining room of this floor plan, with three bedrooms in the half-story above, made up the original structure. There was no evidence of a kitchen wing as part of that original structure. The added first-floor bedroom and pantry are part of a single-story addition that does not show up in this photograph. 
the use of iron nails to reinforce most of the mortise-andtenon joints, the absence of a kitchen wing, and the small scale of the house indicate, however, that the carpenter modified aspects of structure to save money and to take advantage of new products, particularly milled lumber and mass-produced nails. ${ }^{11}$

The ruins of a monumental version of a braced-frame I-house remain visible on the rural Keokuk County landscape (fig. 5). ${ }^{12}$ At one time the abandoned and decaying structure must have looked something like the Elam Jessup farmhouse in Marshall County (fig. 6). Repeating the elevation and floor plan of the traditional I-house type, the broad facades of both houses are balanced by regular placement of two windows on each side of a central portal. An unusually ample kitchen wing extends from the dining room side of the main section of the Keokuk County house.

The heavy braced-frame construction of this Keokuk County I-house represents a transitional system that embodies concepts from both box-frame and balloon-frame con-

11. This Muscatine County I-house was situated on a substantial stone foundation and an $8^{\prime \prime} \times 8^{\prime \prime}$ sill mortised to receive the tenons of $2^{\prime \prime} \times 4^{\prime \prime}$ studs and $2^{\prime \prime} \times 8^{\prime \prime}$ joists set 16 inches on center. $4^{\prime \prime} \times 4^{\prime \prime}$ corner posts had tenons both top and bottom to fit into the mortises of the sill below and a $4^{\prime \prime} \times 4^{\prime \prime}$ plate above. The corner joints of this part of the frame were held together with wooden pegs driven through holes augured through mortise and tenon. To further strengthen the lightweight box frame, the builder used cut iron nails to fasten together the members of the structure.

12. The population of Section 29 of English River Township in Keokuk County provides an example of conditions in which pioneers translated the traditional I-house type to the farmlands of Iowa. Of the eight persons owning land in Section 29 in 1874, two were carpenters who had learned and practiced their trade in Pennsylvania. Both divided time and energies between farming and carpentry after homesteading in Keokuk County. Although there is no description of any farmhouses they built in Iowa or reference to either of them building the structure illustrated here, they probably knew the structure of the I-house type and replicated that kind of house on Iowa farms. The I-house in figure 5 appears to have been originally built for and occupied by S. H. Seaman. See "South English Township," Atlas of Keokuk County Iowa (Clinton, 1874), 21; The History of Keokuk County, Iowa (Des Moines, 1880), 788, 793-96; and A Genealogical and Biographical History of Keokuk County, Iowa (Chicago, 1903), 298-300. 


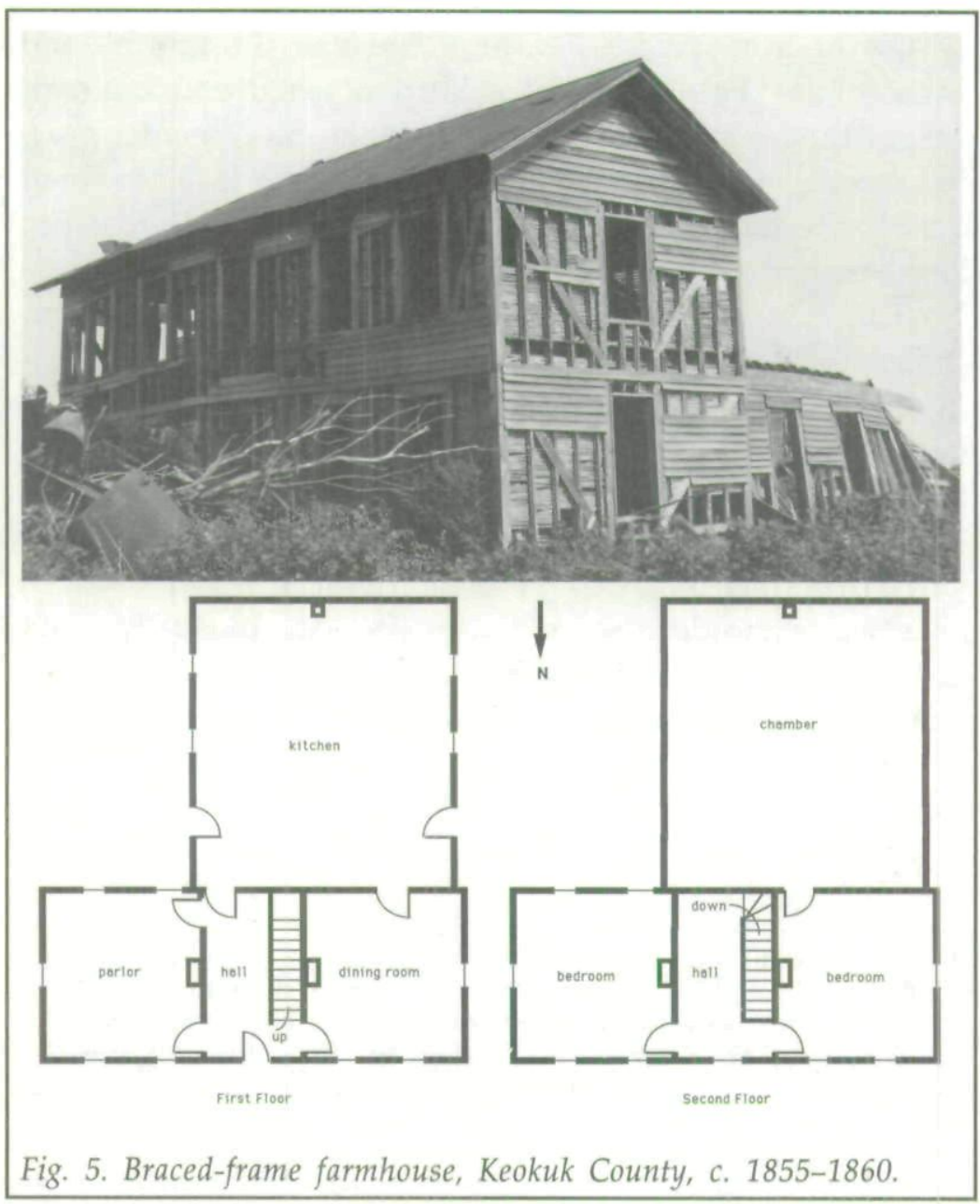

struction. ${ }^{13}$ When the house was built in the in late 1850s, the developing principles of balloon-frame construction were

13. The braced frame of this farmhouse is composed of corner posts that measure $6^{\prime \prime} \times 6^{\prime \prime}$. Both $2^{\prime \prime} \times 6^{\prime \prime}$ studs and $2^{\prime \prime} \times 10^{\prime \prime}$ floor joists are set 16 inches on center and are mortised into a $10^{\prime \prime} \times 10^{\prime \prime}$ sill. Cut iron nails are generously used to secure both diagonal and horizontal braces within the frame as well as fix lath, flooring, and clapboard in place. Instead of one-inch sheathing boards nailed to the studs before the clapboard completes the house's exterior, the spaces between the studs are lathed and plastered to provide an insulating seal between the clapboard and the interior plastered chamber walls. 


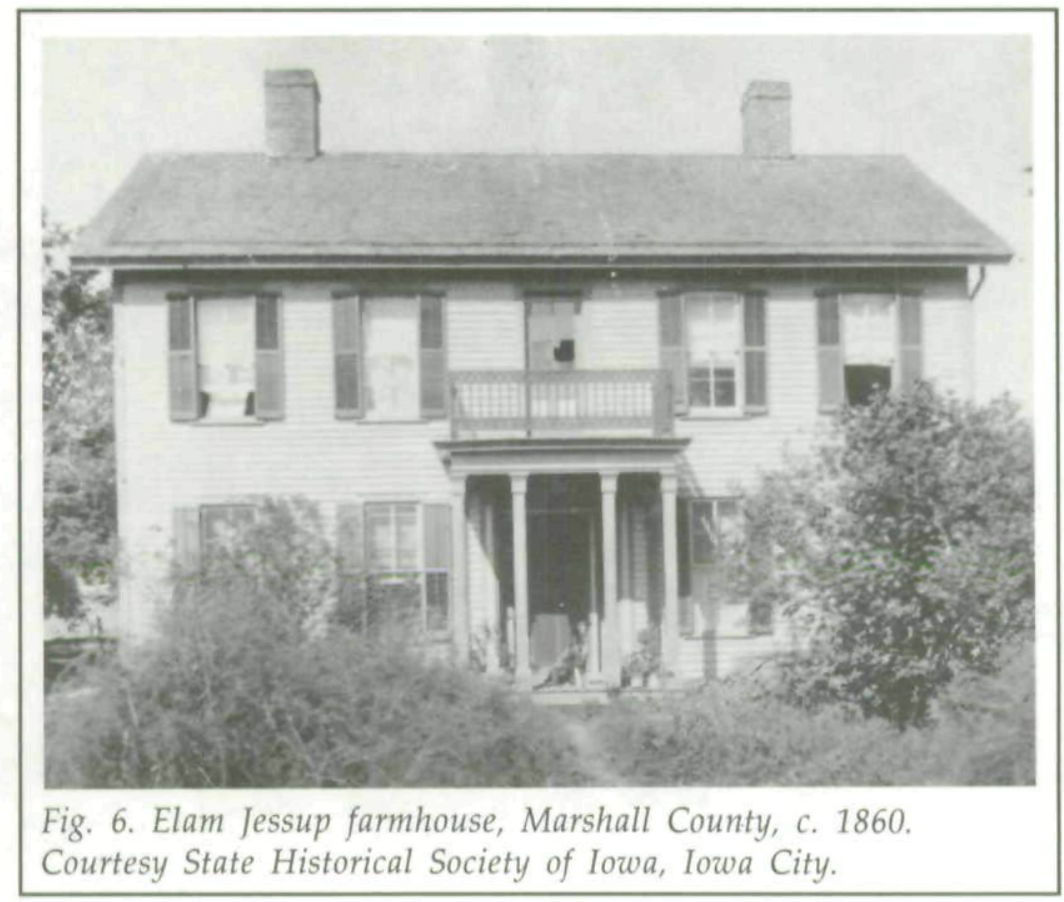

becoming economically attractive. Standard dimension milled lumber and iron nails of various sizes could be purchased at reasonable costs. In such circumstances it became more difficult to justify more costly and time-consuming traditional framing materials and methods. The Keokuk County structure represents a cautious move toward aspects of the new balloon-frame construction while retaining qualities of heavy timber framing. Thus, the internal elements of the building's frame changed while the prestigious appearance of the I-house remained intact.

The house type retained its essential traits when carpenters and farmers built I-houses in the light, thin envelope of balloon-frame construction (figs. 7-10). This new technology resulted in changes in scale and proportion that affected the external appearance of the house. For example, two-story versions of balloon-frame I-houses lacked the full breadth and slender elegance of earlier examples of the house type 


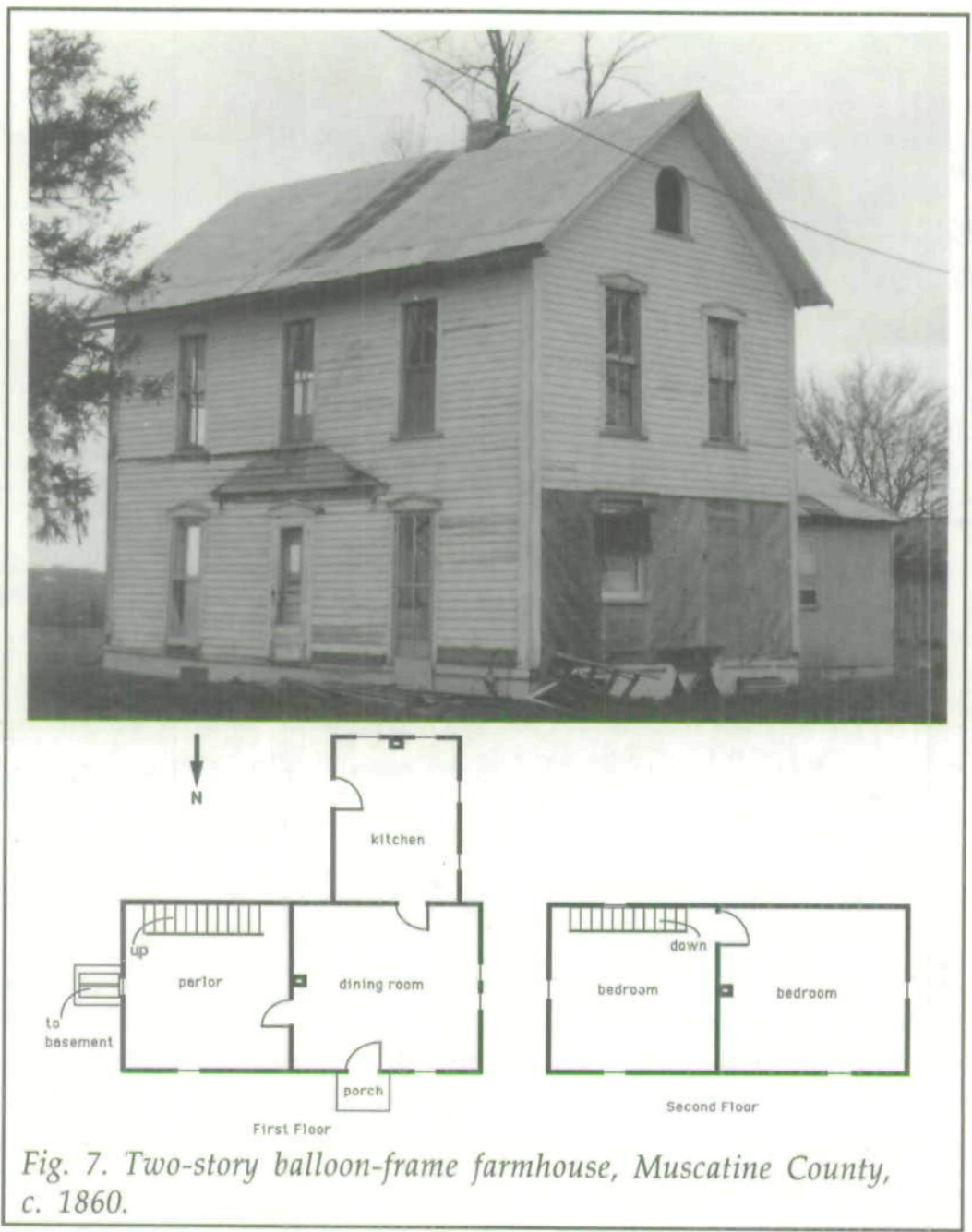

(figs. 7 and 8$).{ }^{14}$ Still, the basic symmetries of the facade and the division of interior spaces remained constant.

14. An economical use of the standard dimension milled lumber in the frames of the two Muscatine County farmhouses may have been the basis for altering the traditional scale and proportions of the I-house. Carpenters and farmer-builders frequently used standard length stud and joist material that was available at the lowest costs and did not trim these members of the balloon frame to fit a predetermined plan and elevation. Joists that were supplied at lengths from twelve to twenty feet could determine the width of both sections of the house, just as standard lengths of $2^{\prime \prime} \times 4^{\prime \prime}$ studs could dictate their height. 


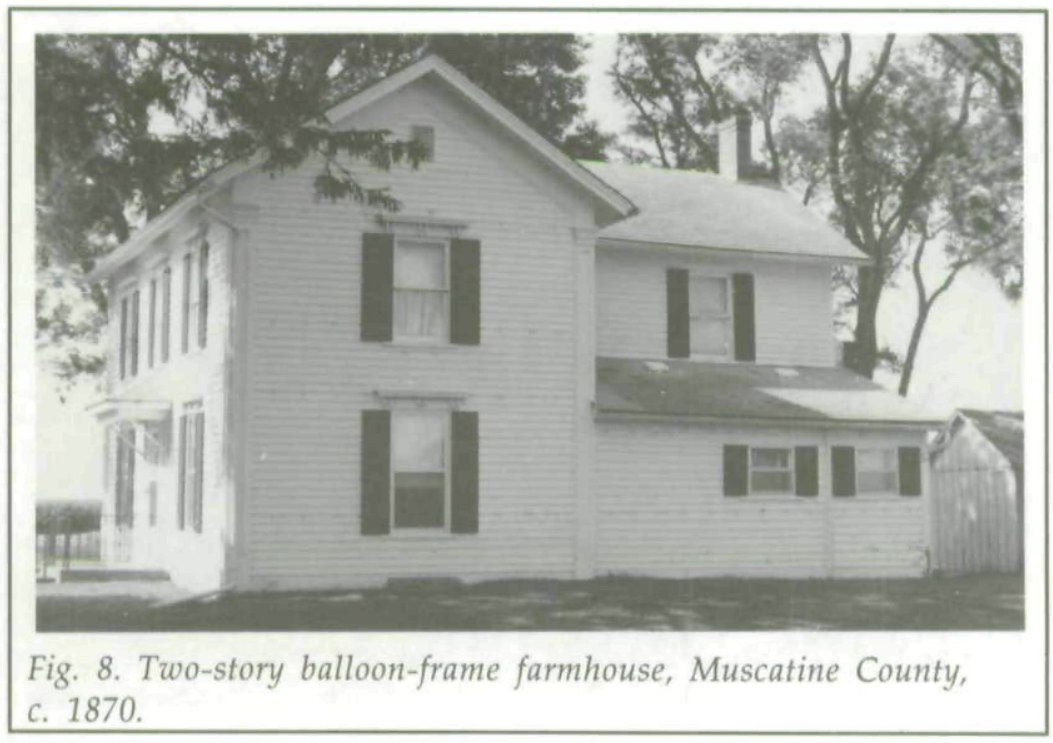

When smaller versions of the I-house began to appear in the $1860 \mathrm{~s}$, they did not supplant the earlier, larger versions of the house type (figs. 9-11). Both interpretations of the traditional form coexisted. The diversity in I-house structure in rural Iowa indicates the extent to which the conservative forces of tradition had been diluted by the 1860 s.

Structural innovations occurred not only on a large scale, but in individual instances as well, as modifications of existing structures adopted the new construction techniques. The two-phase Atalissa I-house, for example, illustrates just such structural change and continuity (fig. 4). Its residents modified the original 1840 s structure in the 1880 s. In this second phase of construction, they used standardized balloon-frame materials and methods to build a large, new two-story unit which became the front section, with a porch and portal. ${ }^{15}$

15. Round wire steel nails joined every $2^{\prime \prime} \times 4^{\prime \prime}$ stud to a $4^{\prime \prime} \times 8^{\prime \prime}$ sill and $2^{\prime \prime} \times 8^{\prime \prime}$ joists to sill and studs. Only two tiers of brick compose a foundation half as thick as the stone basement walls that supported the first phase of the house. 

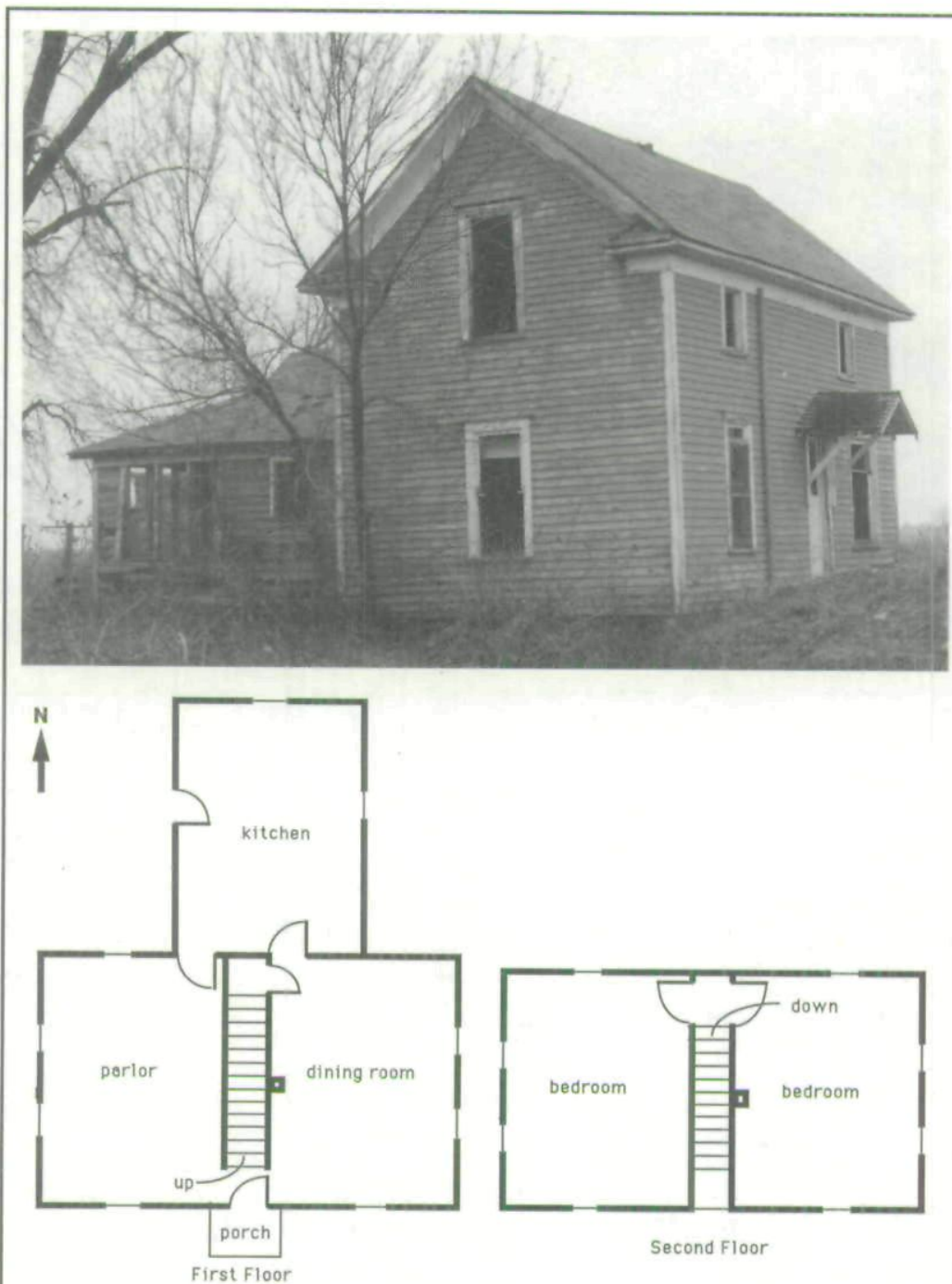

Fig. 9. One-and-one-half-story farmhouse, Keokuk County, c. $1875-1880$.

The two-story elevation, central entrance, and two-room division of the new front section retain the characteristic I-house structure. The exterior appearance of the house was unified by an application of standard dimension clapboard. A bay window opens the dining room to a pleasant southern sun; and the front porch provides a formal approach to the house, 


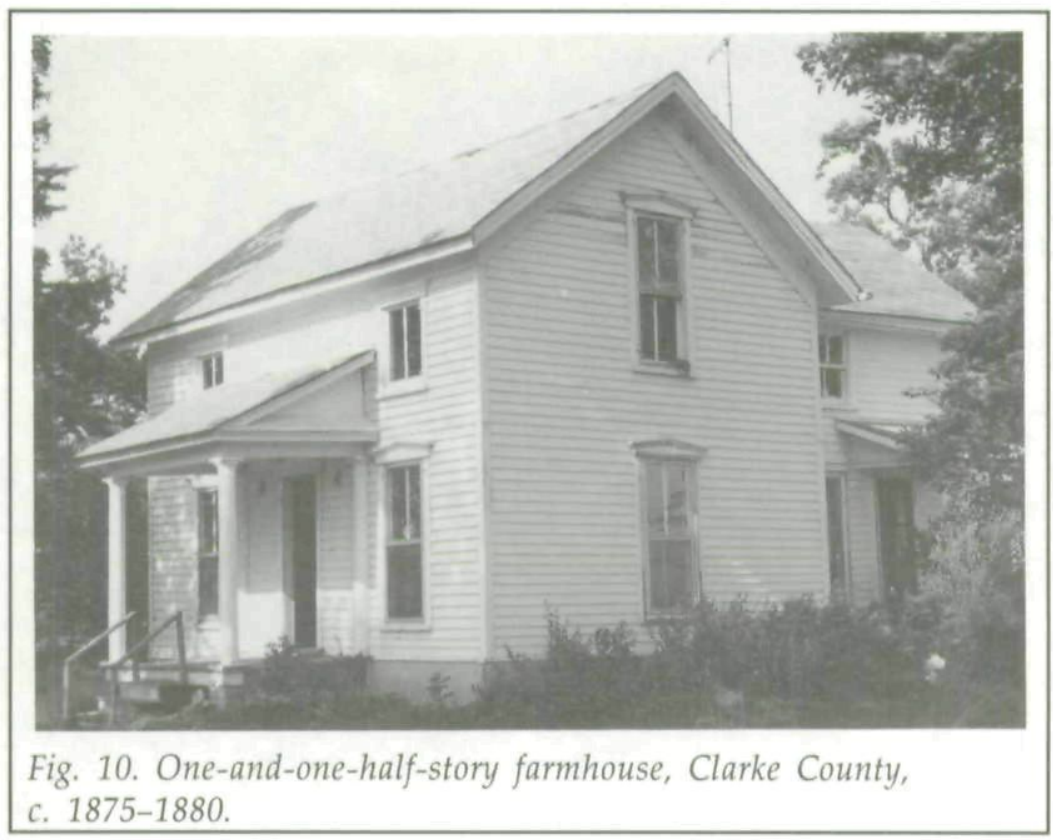

while the side porch offers a more casual entrance. These three features also afford the exterior elevation an irregularity of accent and profile that satisfied the taste for picturesque asymmetry in the 1880 s. And yet a frontal view of the structure still communicates the stately symmetry of the I-house type even when it is fully translated into the lightweight balloon-frame construction. The lightweight box frame of the first house and the balloon-frame construction of the subsequent additions indicate that as the house grew, its builderoccupants sought economy and efficiency even as they preserved meaningful qualities of the past. Essential features of the first house were retained and functioned within the completed whole, allowing its residents to conserve everything that would continue to serve the farm family in their enlarged home. ${ }^{16}$

16. In Cedar County, about twenty miles north of this Muscatine County structure, another farmhouse developed over a period of about forty years from an original I-house built of a heavy box frame composed of rough hewn timbers to a second I-house addition parallel and connected to the first but built of a standard lightweight balloon frame. 


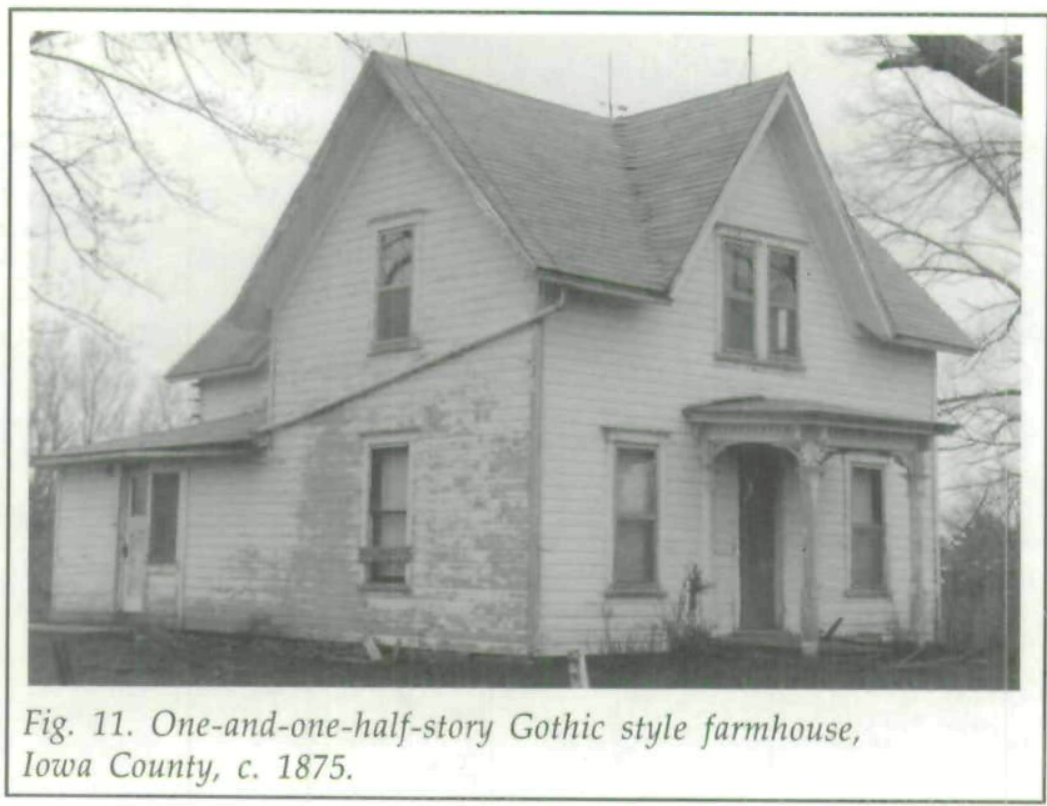

Through their choices to think and build in terms of the I-house type, Yankee farmers in Iowa were maintaining an architectural language that was an integral part of their cultural identity, much as immigrant groups maintained their native language as a means of preserving their ethnic culture in the New World. For these Yankee farmers, structure was the native tongue through which they communicated both basic assumptions and changing preferences about the way one ought to articulate domestic environment.

AS SHELTER a house protects occupants from the elements and helps satisfy the basic physical needs of eating and sleeping. The I-house met those needs in a no-nonsense Yankee fashion. The neat and orderly layout of kitchen, dining room, and bedrooms met the basic needs of eating and sleeping with elegant simplicity. Regardless of scale or materials and methods of construction, the floor plan of the I-house provided easy traffic flow through interior spaces. The regular placement of doors and windows on exterior walls provided good light and ventilation for every room. Second- 
story chambers allowed privacy. Thus, as a structure, the house looked right; as a shelter, it worked well.

The standards for domestic work changed markedly during the second half of the nineteenth century. Builders increasingly judged house floor plans by how convenient the arrangement of rooms was and how efficiently the layout allowed residents to carry out household tasks. A rural contributor to The Cultivator commented, "If there is one thing of more consequence in the construction and arrangement of the farmer's house than another, that thing is CONVENIENCE. . . . As the duties and labors of the farmer's wife are mostly in the house, it becomes a matter of the highest interest that its internal arrangement should be such as to enable her to provide for the wants of her household with the least possible amount of labor." In the typical I-house arrangement, with the kitchen easily accessible from all of the other rooms of the house, "the housekeeper," added another contributor, "can give her orders and see them executed, almost without leaving her room" (that is, the kitchen). ${ }^{17}$

Farmhouse designs characterized as "convenient," "efficient," and "comfortable" appeared regularly in The Cultivator and other nineteenth-century agricultural journals and architectural stylebooks. In 1850 Andrew Jackson Downing suggested a way to adapt the traditional I-house structure to current fashions (fig. 12). His first-floor plan designated a typical arrangement of parlor, living room, and kitchen; but it situated the pantry outside the kitchen wing with difficult passage from the kitchen to the living room through the back entry, central hall, and an antechamber. E. C. Hussey's 1876 version of an I-house elaborated a rear wing containing both kitchen and library plus a second-story chamber (fig. 13). Because some farm families preferred a less formal place for family activities than the parlor, Hussey identified one space in the main unit as a sitting room. Two "progressive" models of the I-house type published in agricultural journals achieved convenience and efficiency by locating the pantry adjacent to the kitchen and taking advantage

17. The Cultivator 3 (1855), 269; ibid. 6 (1858), 184. 


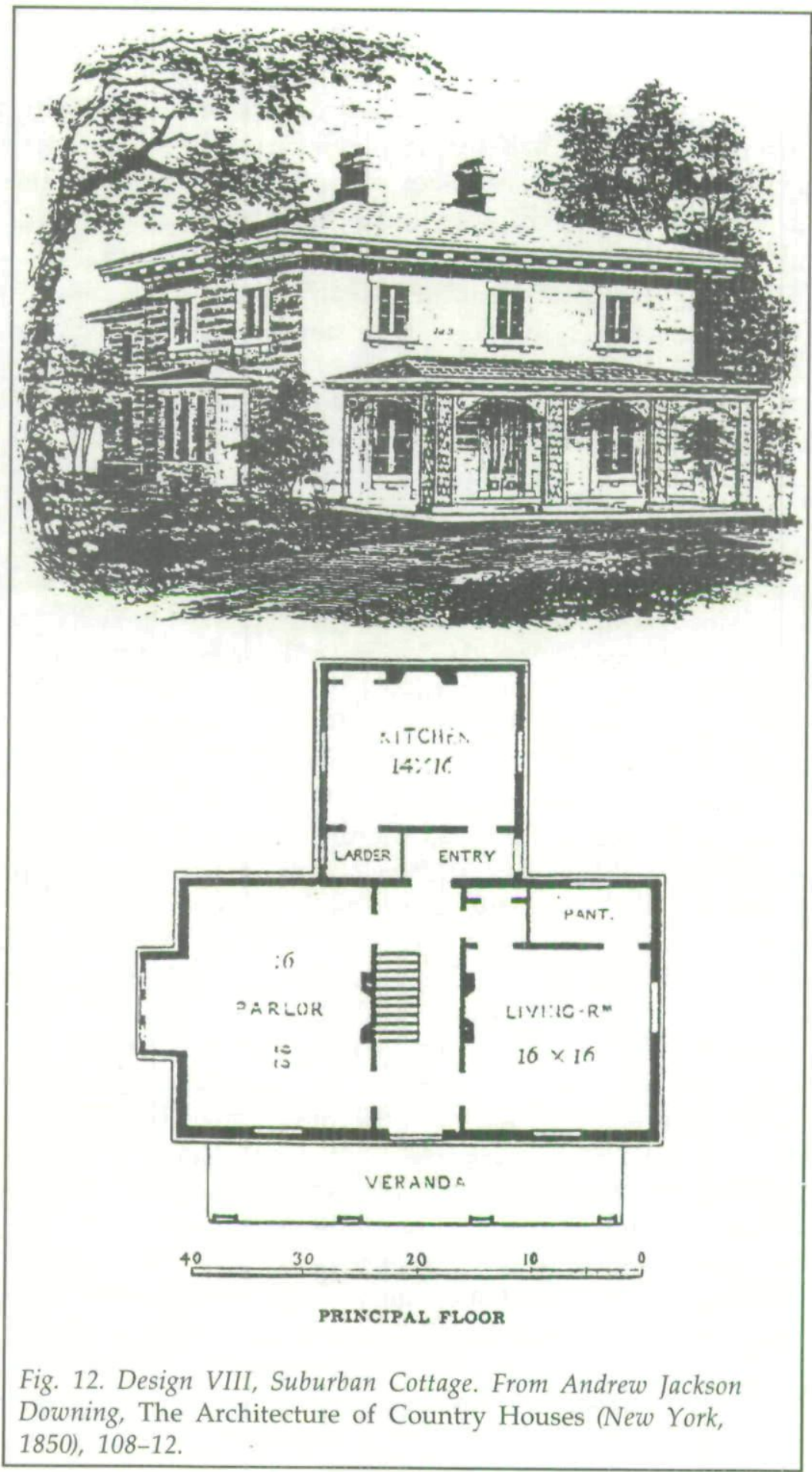




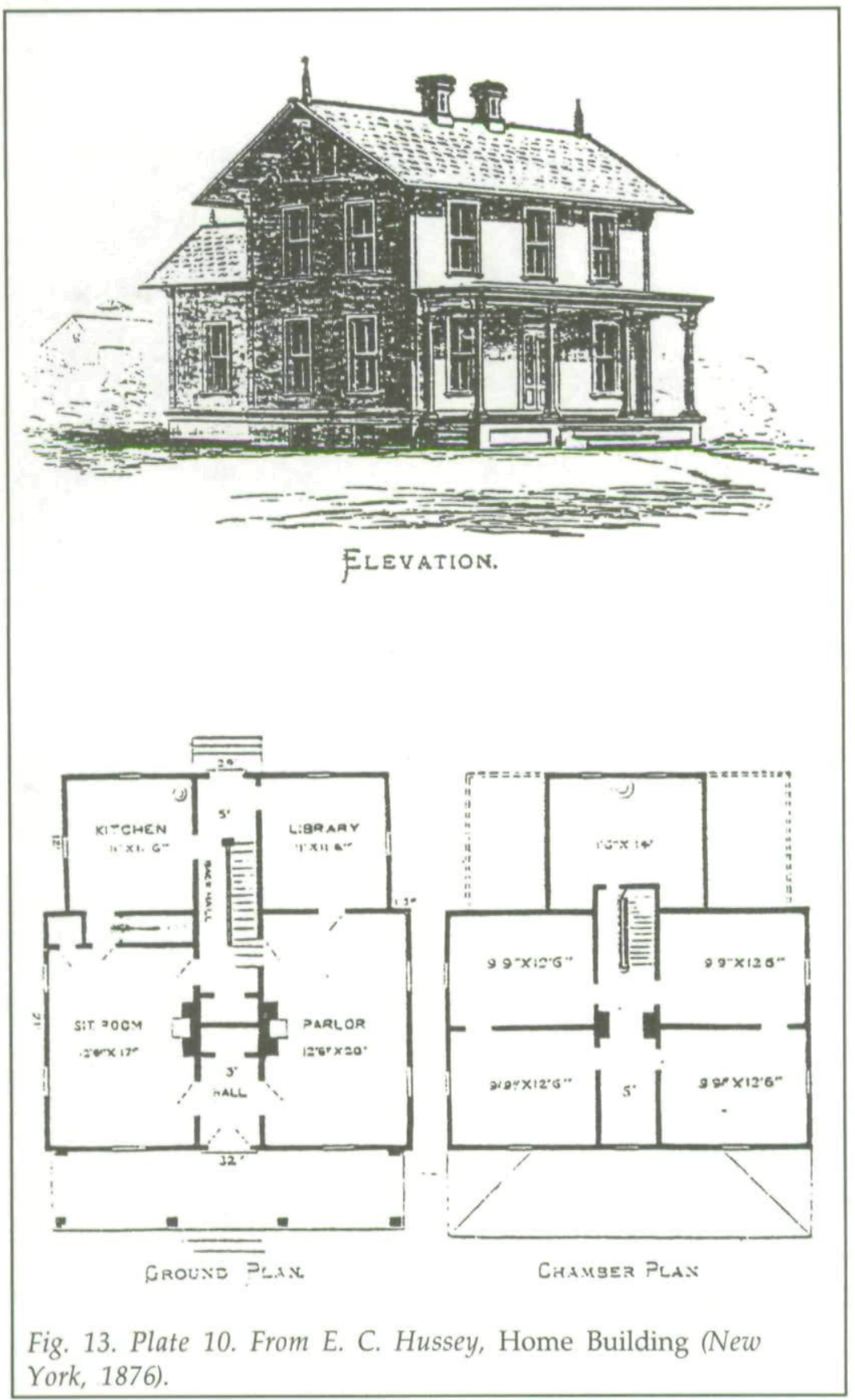




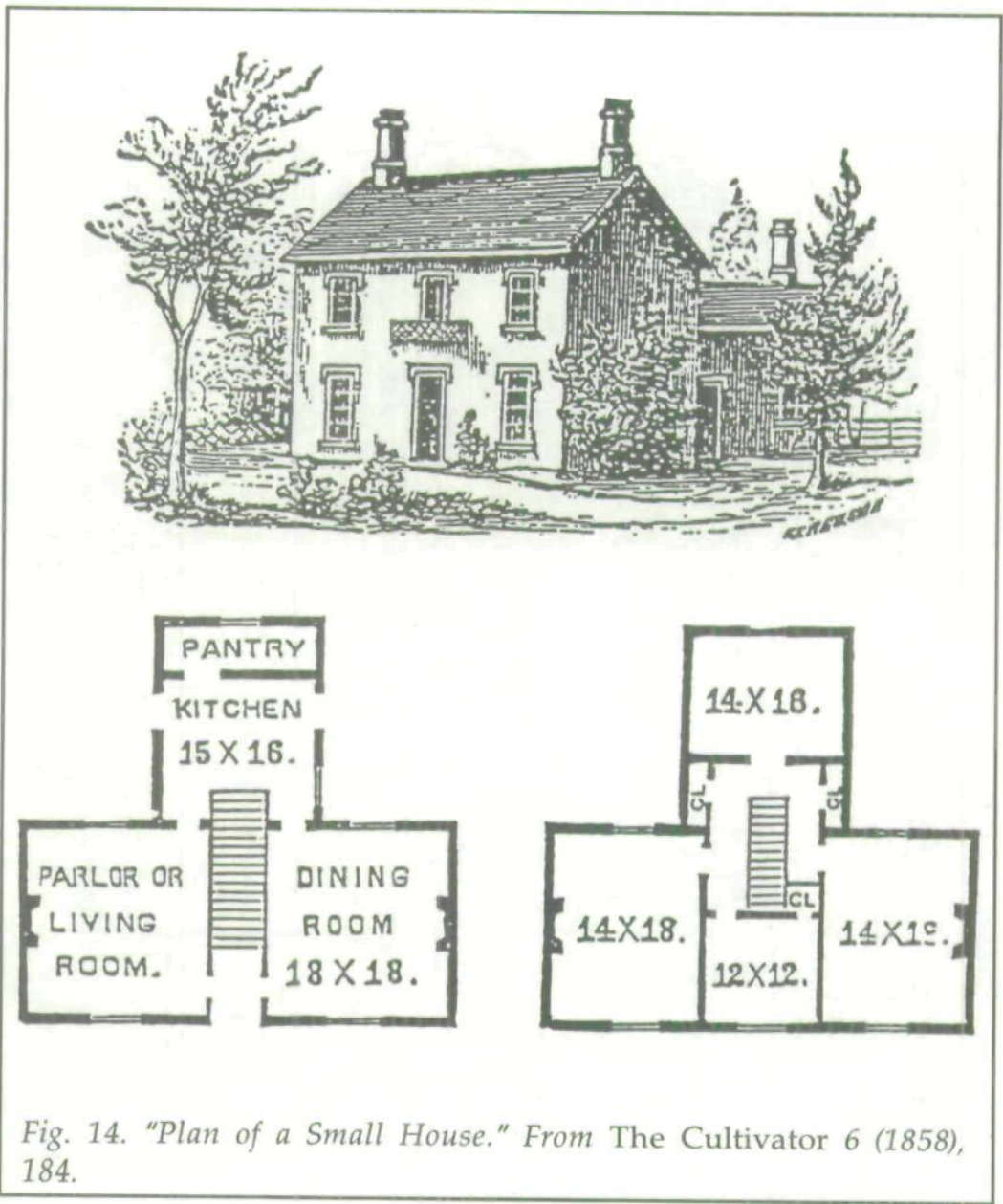

of the space above the wing to extend the staircase, thus saving space in the upstairs chambers (figs. 14-15). ${ }^{18}$

Plans of Iowa I-houses tend to indicate less progressive designs than those in architectural stylebooks and agricultural journals. That is, they retained traditional spaces and did not add special function rooms such as pantries or closets. We

18. Andrew Jackson Downing, The Architecture of Country Houses (New York, 1850), 108-12; E. C. Hussey, Home Building (New York, 1876), plate 10; The Cultivator 6 (1858), 20-21, 184. See also Sally McMurry, Families and Farmhouses in Nineteenth-Century America: Vernacular Design and Social Change (New York, 1988), 135-76. 


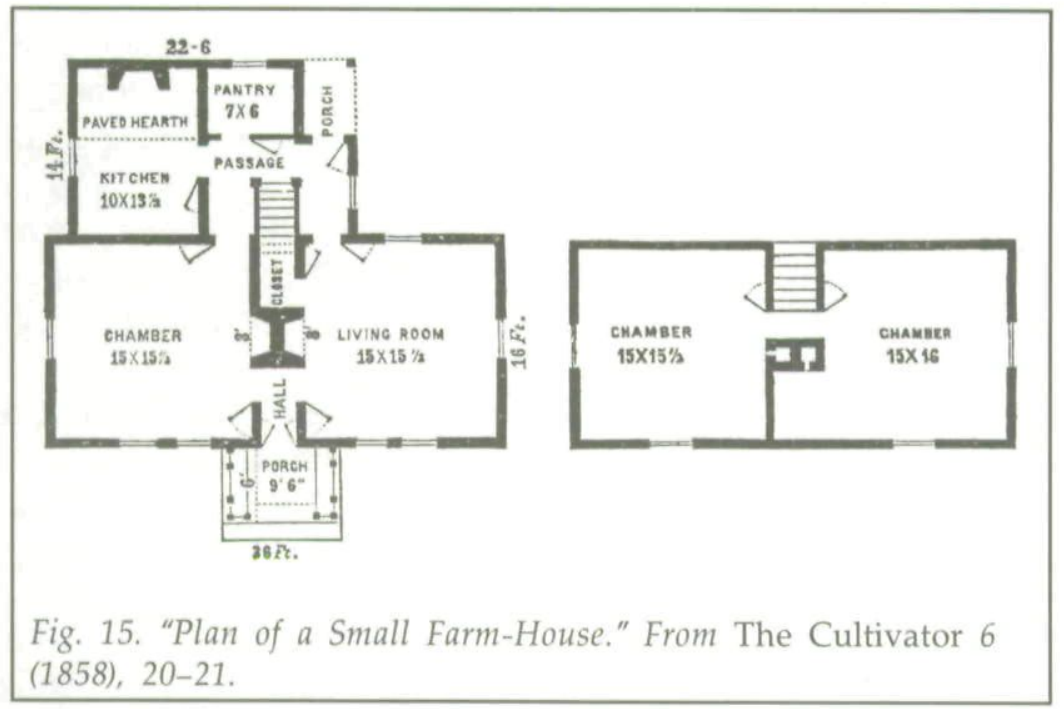

know little about how occupants of Iowa I-houses identified or used spaces in their homes. The persistence of the simple, no-frills layout of rooms does suggest, however, that chambers served traditional purposes. ${ }^{19}$ Small-scale versions of the house type in Iowa also conserved a traditional division of space, indicating that occupants of these economical oneand-a-half story I-houses used the space in their smaller houses in much the same way as residents of larger two-story Iowa I-houses.

Until midcentury the kitchen was considered to be the central work space and family gathering place in the farm home. By the 1870s, kitchen work and women's roles in the household had become more specialized. This change caused some to define the kitchen as a separate unit of the housethe woman's place to do woman's work such as cooking and garden and laundry chores. The kitchen wing of the I-house

19. The tendency to follow traditional ways relates to the frugal, subsistence life-style of Yankee pioneers on the Iowa frontier. After living and working in the small multipurpose space of a log cabin or frame shanty, farm families could be satisfied with the traditional spaces and conveniences of the I-house. See Peterson, Homes in the Heartland, 40-60; Mildred Throne, ed., "Document: Iowa Farm Letters, 1856-1865," Iowa Journal of History 58 (1960), 37-88; and Joseph C. Austin, "An Iowa Farm in the Making: 1867-1900," Annals of Iowa 40 (1970), 306-18. 
served the preferences of each period; it was large enough to fulfill the earlier set of standards, and it was separate enough from the core of the house to be used later as a more specialized domestic work area. ${ }^{20}$

A comparison of the floor plan of the I-house near Atalissa with the design for "A Convenient Farmhouse" illustrates how farm families tried to make it easier to accomplish household chores (figs. 4 and 16). The 1874 American Agriculturist design offered to the farmer "a plan whereby he can build a small house to which by and by he can add a front, and thus secure as many conveniences as possible without unnecessary present expense." ${ }^{21}$ By adjusting and adapting old and new spaces of a house over a period of time and under varying circumstances, occupants could suit their changing needs and preferences while preserving a traditional way of arranging interior spaces. The Atalissa farmhouse, like the "convenient" design, retained the kitchen and dining room while adding the ample living room and formal parlor on the front and the convenient back bedroom and pantry off the kitchen in the rear. The arrangement of chambers and halls on the second story of the I-house gave each room easy and individual access to the original staircase from the kitchen. It is through this convenient, centrally located passage that one would ascend to bedrooms heated by iron stoves connected to the chimneys of the original house, and descend to the warmth of the kitchen to receive the sustenance served from the cooking range.

By the 1880s, the Yankee pioneers were well established on their Iowa farms and were demanding that their shelters provide a higher level of domestic comfort. The traditional fireplace and large chimney could not comfortably heat all of the rooms in an I-house; it would have taken three to five such units to do so. Downing's floor plans and The Cultivator's designs indicated large fireplaces and chimneys traditionally located on the end gable walls or the walls of the central passage and on the end wall of the kitchen wing (figs.

20. See McMurry, Families and Farmhouses, 87-134; and Peterson, Homes in the Heartland, 80-95.

21. "A Convenient Farmhouse," The American Agriculturist 33 (1874), 21.7. 


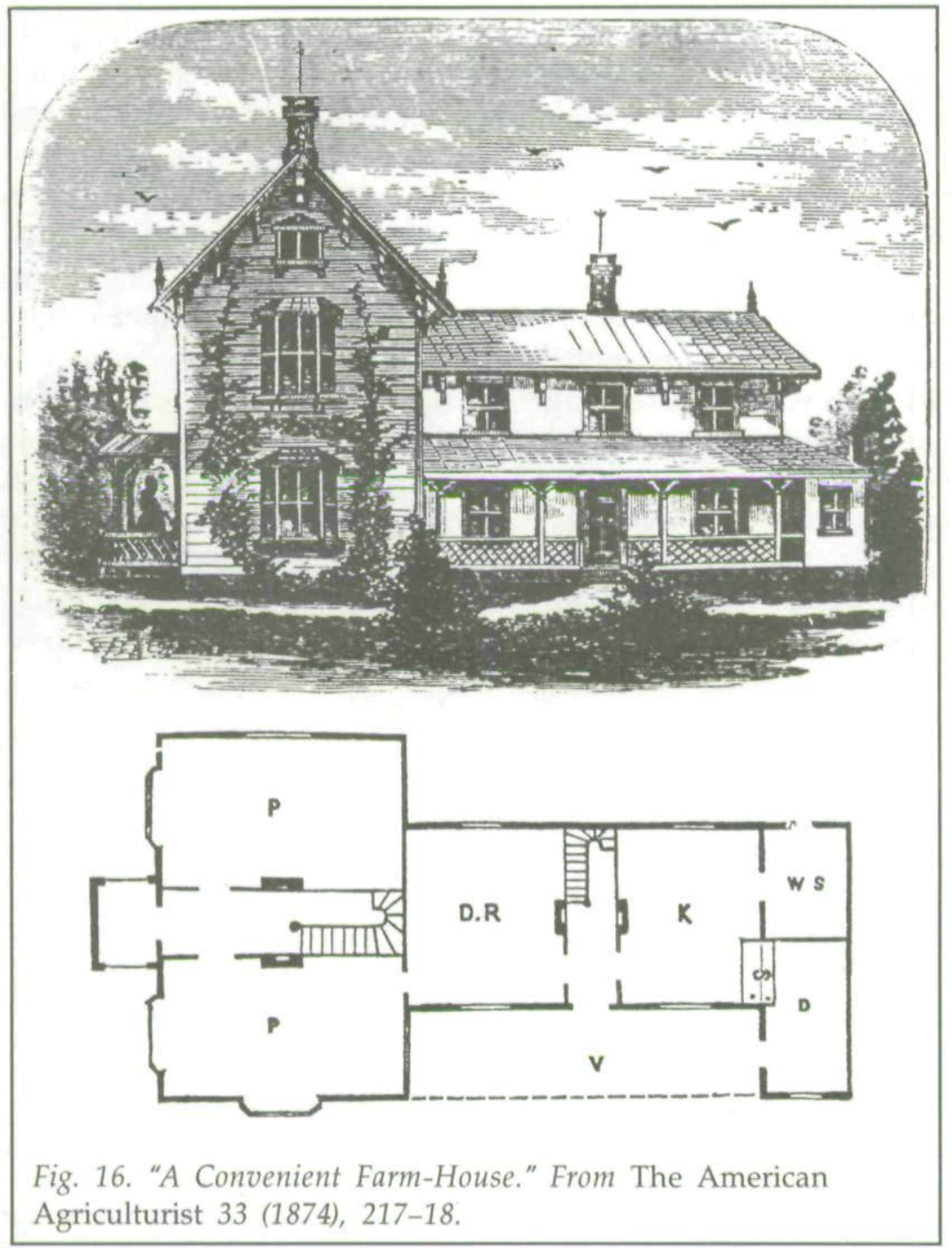

12, 14, and 15). The author of the "Plan of a Small FarmHouse" suggested replacing the large kitchen hearth with an "ordinary cooking stove" and "simple flue," but recognized that "those who have never used cooking stoves, are not always willing to incur the expense of buying one." 22

The ease of adapting the I-house to a central chimney and heating stoves again demonstrates the basic practicality

22. The Cultivator 6 (1858), 20. 
of the traditional house type (figs. 7 and 9). Placing the cooking range and chimney at the far end of the kitchen wing kept excessive heat from the main unit of the house during summer months. The location of the chimney on the central wall of the main unit permitted installation of a stove in virtually any room in the two-story layout. And a central staircase facilitated convection of heat to the upper story and helped take the chill off those chambers, even when they were not furnished with a heating stove. ${ }^{23}$

Through every stage of agricultural development in Iowa, many farmers selected the I-house type as suitable shelter partly because the house type economically satisfied basic physical needs. With its symmetrical layout of interior spaces, the I-house type could be adapted to changing demands and preferences for keeping house conveniently and efficiently in a healthy and comfortable domestic environment.

THE STRENGTH AND UTILITY of I-houses led occupants to envision them as long-term dwellings, habitations where families could make a place for themselves in a community and practice and pass on traditional ways from generation to generation. As a type of dwelling commonly identified with successful farmers during the eighteenth and early nineteenth centuries in eastern and southern states, the I-house met socioeconomic as well as physical needs and desires. ${ }^{24}$ Its breadth, elevation, and stately, formal balance invested the structure with architectural import and distinguished it from smaller one-story farmhouses. The long principal facade of the house that faced the road offered an impressive aspect of the structure to public view. Thus the I-house, with its formal balance and simple monumentality, reflected the stability and

23. Popular house designs published in architectural stylebooks, agricultural journals, and lumber yard plan books appealed to a taste for picturesque asymmetrical layouts. The interiors of such houses were relatively more difficult to heat because the rooms were not all linked to a central hall and staircase.

24. Kniffen, "Folk Housing," 555; Howard Wight Marshall, Folk Architecture in Little Dixie: A Regional Culture in Missouri (Columbia, MO, 1981), $62-71$. 
socioeconomic importance of families holding the most influential positions in rural communities.

The materials and methods used to construct the structures could add to the impression of stability and endurance. I-houses constructed of stone or brick, box frame or heavy braced frame, manifested the residents' desire to appear rooted and secure (figs. 2-5). In rural Iowa, for example, the durable materials used in the Edwin G. Hosch stone farmhouse near Cascade and the Samuel Nichols brick dwelling near Nichols invested those structures with qualities of strength and permanence (figs. 2 and 3 ).

Balloon-frame I-houses seemed to represent some compromise of standards of endurance, and to project a relatively less impressive display of substantial position within the rural community. Eventually, however, farmers and carpenters became convinced that balloon-frame construction could ensure the same strength, durability, and integrity of building as did the time-tested box-frame method. As the economies of balloon-frame construction brought the high status of the I-house type within the reach of many farm families, its appearance became relatively less manorial while retaining some of the formal dignity of I-houses built using traditional materials and methods (figs. 7-10).

As egalitarian qualities replaced the more aristocratic ones originally associated with the house type, traditional forms and values fell victim to the vacillating currents of popular taste. ${ }^{25}$ More families exercised greater freedom in the ways they chose to finish the external appearance of their homes, thus enabling them to achieve a semblance of domestic elegance. Decorated versions of Iowa I-houses illustrate the effect of popular taste on traditional design. Vestiges of

25. The situation described here is not a diffusion of the house-type from the socially elite to the untutored, lower-class vernacular. The changes that made the I-house type affordable for more farm families in Iowa were the result of the availability of a wider range of choices in construction methods and the consequent greater variety of sizes and proportions of farmhouses. See Dell Upton, "Towards a Performance Theory of Vernacular Architecture: Early Tidewater Virginia as a Case Study," Folklore Forum 12 (1979), 173-96, for a discussion and critique of the social diffusion theory of house-types. 
Federal style decoration in the vernacular versions can be noted in the use of classical columns, returns of the eaves that frame the gable wall, and pedimented porches and heads on the window framing (figs. 7-10).

The Robert Graham farm family certainly exercised its options to generate a more up-to-date appearance of the I-house when they built their house north of Brooklyn, Iowa, in the 1880 s (see cover). The house is so embellished with architectural features preferred at the time of its construction that it is difficult to discern the form of the traditional I-house as the core of its design. The builder applied to the surface of the I-house structure a central projecting pavilion and tower, bay window with a false balcony, classical eave molding, and curved eyebrow-like heads on the double windows. The Grahams apparently wanted to live in the best of two worlds - the time-tested formula of a traditional I-house type and the latest passing fashion in stylistic elaboration. Tradition and taste create an uneasy alliance in this version of the house type.

As planners and builders realized the flexibility and adaptability of floor plans and elevations in balloon-frame construction, they developed an enormous variety of individual houses. ${ }^{26}$ Yet despite opportunities to design houses uniquely suited to their occupants, the I-house type remained popular as a basis of design for Iowa farmhouses. The traditional form of the I-house offered a sense of permanence and stability during a period of great change. It was the choice of those rural Iowans who wanted to conserve traditional values that promised continuity with the past and perspective toward an uncertain future.

THE I-HOUSE TYPE was formed according to what the builder-occupants considered to be intrinsically proper American ideals and values about family and home. At the outset of settlement in Iowa, values that defined a house as home originated within the groups of Anglo-American migrants who established farms in the eastern part of the state. These Yankee farmers tended to see themselves as a homogeneous

26. Peterson, Homes in the Heartland, 25-39. 
group of American citizens, with an innate sense of right and justice, pious but religiously tolerant, and sharing a common purpose to establish "new and independent homes" in the new territory. ${ }^{27}$

External forces also shaped the house type as home. After 1850, during the second generation of settlement in Iowa, the ideals and values of family and home were increasingly defined by professionals, preachers, and reformers. Newspaper articles, farm journals, "house and home" columns, etiquette books, Sunday School lessons, sermons, and political oratory prescribed rules that, if followed, would supposedly enable families to establish and maintain strong moral growth in the proper domestic environment. Authors of these didactic pieces attempted to persuade Americans to accept and follow a national consensus that the family constituted the basis of social and political order and, indeed, the good life. ${ }^{28}$

Planners and architects participated fully in this consensus and created architectural styles to promote the prescribed values. Andrew Jackson Downing was a leading proponent of family values at midcentury. Writing in The Architecture of Country Houses, Downing asserted that "a fitting, tasteful, and significant dwelling is a powerful means of civilization." He identified country homes as the places where social, moral, and aesthetic values were taught and preserved, and concluded that "the condition of the family home-in this country where every man may have a home-should be raised, till it shall symbolize the best character and pursuits, and the dearest affections and enjoyments of social life."29

Downing and other professionals wanted to shape a national identity focused in a proper domestic environment, served by modern design, and formed by Anglo-Saxon Prot-

27. Charles A. White, "The Early Homes and Home-Makers of Iowa," Annals of Iowa 4 (1899), 179.

28. For discussions of domestic environment and the family in nineteenthcentury America, see Clifford Edward Clark, Jr., The American Family Home, 1800-1960 (Chapel Hill, NC, 1986); Jan Cohn, The Palace or the Poorhouse: The American House as a Cultural Symbol (East Lansing, MI, 1979); and McMurry, Families and Farmhouses.

29. Downing, Architecture of Country Houses, xx. 


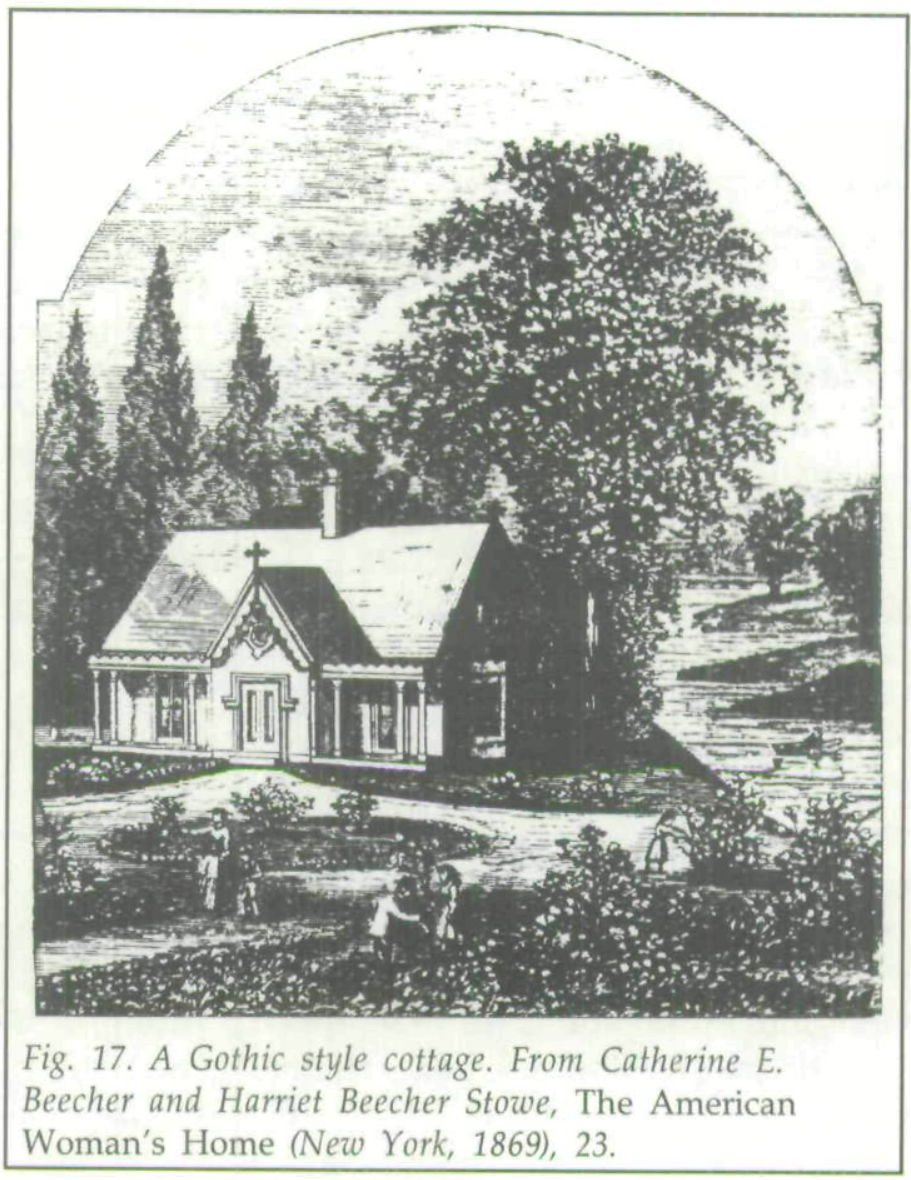

estant values. Because Downing and his many followers romantically perceived the Middle Ages as essentially Christian, they promoted a picturesque Gothic revival style as one ideal kind of home in which the American family could realize its potential. The model home offered in Catherine Beecher and Harriet Beecher Stowe's The American Woman's Home was a combination of a one-and-one-half story I-house and a Gothic cottage (fig. 17). The central gable crowned with a cross identified the quality of family life one would expect to find in passing through this portal. The faith, piety, and morals of that age were associated with the Gothic style house, which, as a home, would foster the bourgeois values of the American urban middle class. 
Anglo-American farmers in nineteenth-century Iowa did not generally relate sympathetically to the concerns of the urban bourgeois. Yet many rural Iowans did, in fact, choose to build farmhouses in picturesque styles popular from the $1860 \mathrm{~s}$ to the $1890 \mathrm{~s}$. While these modern alternatives for an appropriate kind of house were current, many Iowa farmers continued to build updated versions of the I-house. Retaining essential structural characteristics, some farmers added a central, steeply pitched gable to the major facade of the I-house to give it a Gothic appearance not too different from the model home featured in The American Woman's Home (figs. 11 and 17). ${ }^{30}$ The Graham farmhouse also illustrates how farm families responded to popular tastes and prescriptive norms for the American family in the 1880s (cover). Despite considerable social and moral persuasion to clothe the family in the new aesthetic of the American home, many Iowa farmers maintained what they considered to be the traditional American image-one that upheld values they had inherited from their own past.

THE TERMS structure, shelter, dwelling, and home represent a cluster of ideas, images, and values that help to explain ways farm families and local carpenters maintained traditional qualities while planning and building new houses. The four concepts also help us understand how these carpenters and farmer-builders modified aspects of traditional ways of doing things to achieve currently viable and popular results from their labors.

30. Gothic versions of the I-house illustrate both traditional and modern qualities of the house type. Tarpley Early Taylor built a Gothic style I-house for his family in Van Buren County in 1866. The Taylor family dated back to 1635 in York County, Virginia. The branch of the eighth generation that pioneered in Iowa migrated west by way of Kentucky. See Henry C. Taylor, Tarpleywick: A Century of Iowa Farming (Ames, 1970), 3, 28. The central gable I-house also became the basis for a modern adaptation of the house type published by Sears, Roebuck \& Co. in 1908. "Modern Home No. 105," in Book of Modern Homes (Chicago, 1908), was a standardized, mass-produced, pre-cut, ready-to-assemble design related to hand-crafted Iowa I-houses. "Modern Home No. 105" was a distant cousin that left the farm to live in the city. However "fancied up" the Sears house appears, it bears a striking family resemblance to the traditional I-house type. 
Transfer and transformation of the I-house type began when dwellings of this kind were built early in Iowa's history. Community pressure to adhere strictly to traditional ways diminished when Anglo-American farmers migrated from the homes of their elders. The families that decided to venture to new territories were more prone to depart from traditional ways. The generation of the 1830 s was open to new experience, ready to realize personal ambition for themselves and for their children through work and thrift and planning. ${ }^{31}$ Within the first groups of Iowa settlers and in subsequent generations, there were imaginative, inventive individuals who adapted what was brought along from the old homestead to the conditions in new territory. These were the craftsmen who worked effectively to satisfy immediate needs for housing on the frontier by using available materials and means to construct shelters. Later, they took advantage of the opportunity to use newly available materials and techniques-milled lumber, cut nails, and balloon-frame construction-to achieve economy, efficiency, and adaptability in building farmhouses. They also worked to satisfy the aesthetic preferences of their clients for houses that appeared to keep current with popular tastes and at the same time preserved the appearance and prestige of the traditional form.

Despite innovations in structure, carpenters and farmerbuilders preserved the basic elevation and floor plan characteristic of the house type. They continued to work with the traditional form when the general availability of the type for "middling" farmers led to the construction of I-houses on a smaller scale and in varying proportions. Even when farmers chose from increasingly varied schemes of decoration, the tradition survived. Despite external cosmetics and changes in structural materials and methods, the I-house type remained the form to which many Iowa carpenters and farmer-builders applied their imagination and skill.

The ideas and values that informed adaptations of the I-house type as shelter, dwelling, and home were influenced by national trends that defined the domestic environment as

31. Richard D. Brown, Modernization: The Transformation of American Life, 1600-1865 (New York, 1976), 95. 
a place where occupants should be able to perform household tasks conveniently, comfortably, and efficiently and where the American family would endure as a basic contributor to the moral fiber of the nation. The continuity and change evident in the traditional I-house in rural Iowa reflect the beliefs, values, and practices that shaped the physical and spiritual dimensions of Iowa's rural landscape.

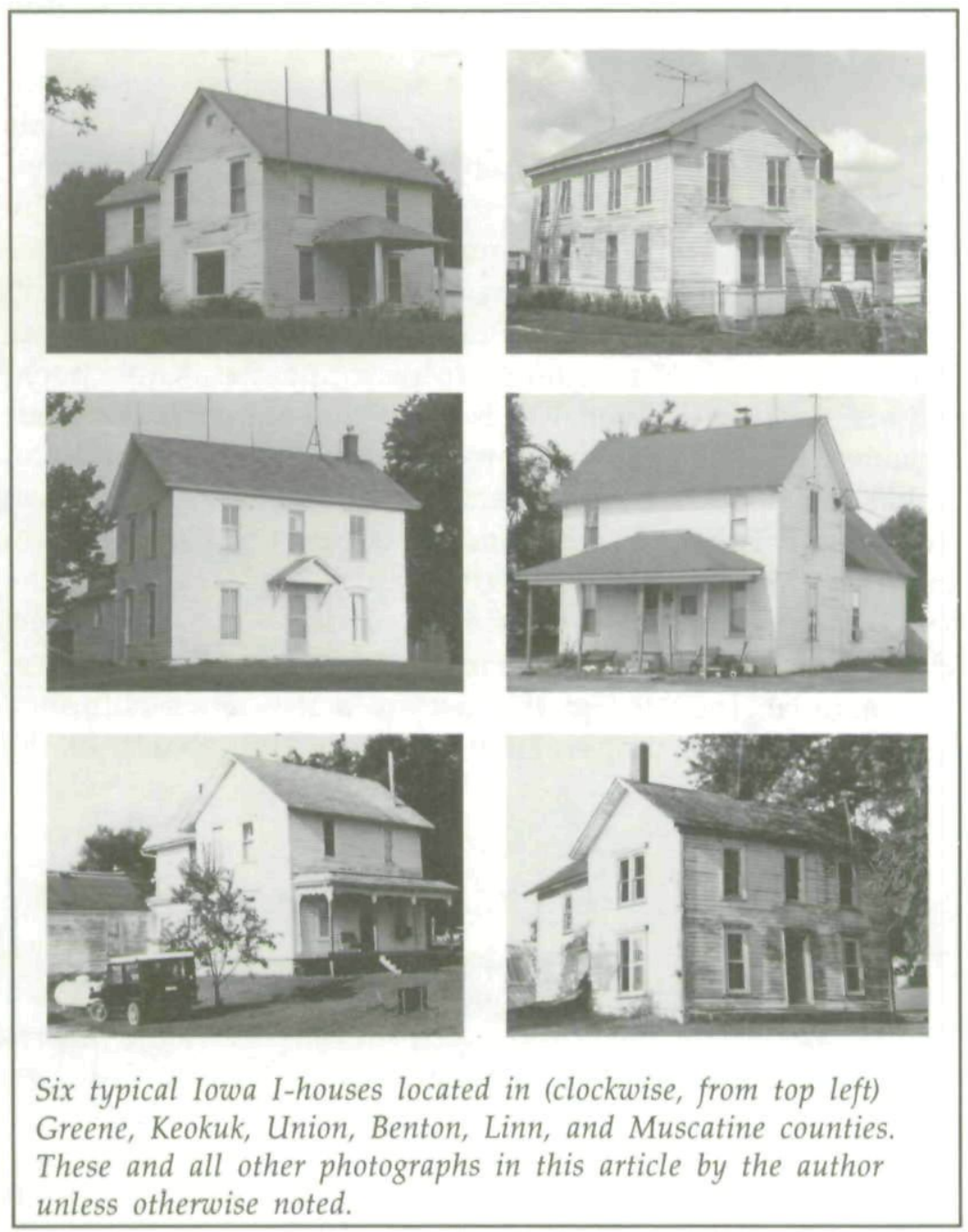


Copyright of Annals of Iowa is the property of State of Iowa, by \& through the State Historical Society of Iowa and its content may not be copied or emailed to multiple sites or posted to a listserv without the copyright holder's express written permission. However, users may print, download, or email articles for individual use. 